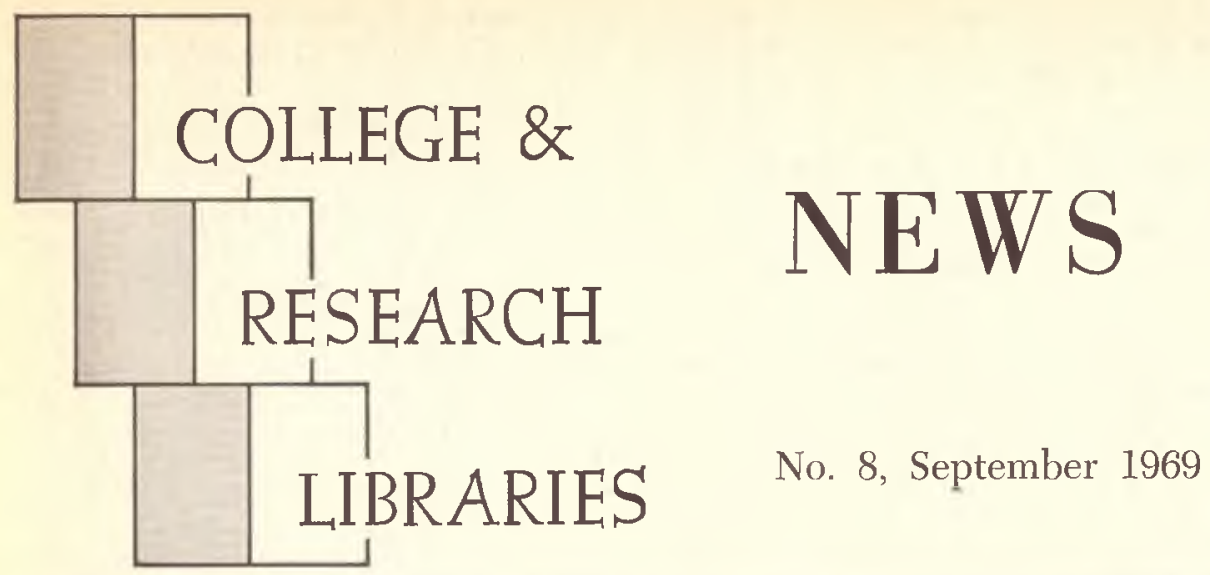

ACRL News Issue (A) of College \& Research Libraries, Vol. 30, No. 5

\title{
Pittsburgh Ad Hoc Committee Against the Library Cut
}

Students and faculty members of the graduate school of library and information sciences of the University of Pittsburgh have formed the Pittsburgh Ad Hoc Committee Against the Library Cut, to take action in opposition to the budget proposal now before Congress which would cut federal aid to libraries by 66 per cent. Andrew D. Armitage, Chairman, and most of the other committee members were delegates to the Congress for Change in Washington, D.C., in June. After returning from CFC, the Pitt delegates met with other GSLIS students and faculty members and decided to organize as a group to act on this issue, one which is representative of the questions which concerned the Congress for Change.

The Ad Hoc Committee contacted over 300 Pennsylvania libraries, accredited library schools throughout the country, and other interested groups, and hopes to attract substantial support from outside the library profession. The Committee has issued a statement detailing potential effects of a budget cut on specific programs of library service, along with a petition on which the Committee hopes to obtain 5,000 signatures. Copies of the petition and a list of signers will be sent to members of the House and Senate committees and subcommittees through which the relevant sections of the appropriations bill must pass. A publicity campaign in the Pittsburgh area and in library journals will be accelerated by the Committee as action proceeds on the bill.

For this campaign to be successful, it is necessary to gain the support of a large and diverse group of people. Andrew Armitage, Chairman of the Pittsburgh group, suggests that concerned individuals both within and outside the library profession write letters to Congressmen and Senators, form local groups in their own areas, petition Congress, begin publicity campaigns to inform the public of the informational and educational losses to be suffered if the proposed budget cut is approved.

For further information contact: Andrew D. Armitage, Chairman, Pittsburgh Ad Hoc Committee Against the Library Cut, 5737 Holden Street, Apt. B, Pittsburgh, Pennsylvania 15232. Phone: (412) $362-4165$ or $621-3500$, Ext. 7454 .

\section{DOWNS AWARD}

LeRoy Charles Merritt, dean of the school of librarianship at the University of Oregon, is recipient of the first Robert B. Downs Award for outstanding contribution to intellectual freedom in libraries. The $\$ 500$ award was presented June 25 at the annual alumni meeting of the University of Illinois graduate school of library science during the American Library Association Convention in Atlantic City.

The U. of I. school of library science is sponsor of the awand, created to honor Robert Downs, dean of library administration at the U. of I. Urbana-Champaign campus, for his stands for freedom from censorship for libraries 